\title{
Squamous Cell Neoplasm
}

National Cancer Institute

\section{Source}

National Cancer Institute. Squamous Cell Neoplasm. NCI Thesaurus. Code C3792.

A neoplasm that is composed of squamous epithelial cells. Squamous cell carcinoma is a representative example. 